\title{
Managing groundwater supplies subject to drought: perspectives on current status and future priorities from England (UK)
}

\author{
M. J. Ascott ${ }^{1}$ (1) • J. P. Bloomfield ${ }^{1}$ - I. Karapanos ${ }^{2}$ - C. R. Jackson ${ }^{3}$ - R. S. Ward ${ }^{3}$ - A. B. McBride ${ }^{4}$ B. Dobson ${ }^{5}$. \\ N. Kieboom ${ }^{6}$ - I. P. Holman ${ }^{7}$ A. F. Van Loon ${ }^{8}$ - E. J. Crane ${ }^{1}$ • B. Brauns ${ }^{3}$ - A. Rodriguez-Yebra ${ }^{3,5} \cdot$ K. A. Upton ${ }^{9}$
}

Received: 18 March 2020 / Accepted: 23 September 2020 / Published online: 23 October 2020

(C) The Author(s) 2020

\begin{abstract}
Effective management of groundwater resources during drought is essential. How is groundwater currently managed during droughts, and in the face of environmental change, what should be the future priorities? Four themes are explored, from the perspective of groundwater management in England (UK): (1) integration of drought definitions; (2) enhanced fundamental monitoring; (3) integrated modelling of groundwater in the water cycle; and (4) better information sharing. Whilst these themes are considered in the context of England, globally, they are relevant wherever groundwater is affected by drought.
\end{abstract}

Keywords Groundwater management $\cdot$ Water supply $\cdot$ Drought $\cdot$ UK

\section{Introduction}

Globally, groundwater provides almost $50 \%$ of all drinking water (Smith et al. 2016). Consequently, the impact of droughts on groundwater is a major threat to water security, which may be exacerbated by future environmental change. Anthropogenic

M. J. Ascott

matta@bgs.ac.uk

1 British Geological Survey, Maclean Building, Benson Lane, Crowmarsh Gifford, Oxfordshire OX10 8BB, UK

2 Affinity Water Limited, Tamblin Way, Hatfield, Hertfordshire AL10 9EZ, UK

3 British Geological Survey, Keyworth, Nottinghamshire NG12 5GG, UK

4 HR Wallingford, Howbery Park, Wallingford, Oxfordshire OX10 8BA, UK

5 Imperial College London, Skempton Building, London SW7 2BB, UK

6 Environment Agency, Horizon House, Deanery Road, Bristol BS1 $5 \mathrm{AH}, \mathrm{UK}$

7 Cranfield Water Science Institute, Cranfield University, Cranfield, Bedford MK43 0AL, UK

8 Institute for Environmental Studies (IVM), Vrije Universiteit, Amsterdam, Netherlands

9 British Geological Survey, The Lyell Centre, Research Avenue South, Edinburgh EH14 4AP, UK warming has already been shown to affect groundwater droughts in the UK (Bloomfield et al. 2019), and increases in pumping are predicted to increase global groundwater depletion (Wada et al. 2012). In light of these pressures, effective management of groundwater during drought is essential. It has been recently highlighted that improved long-term governance and management is needed to achieve groundwater sustainability (Global Groundwater Statement 2019). In this context, it is timely to consider the status of groundwater management concerning drought, and identify priorities for future research and practice. This paper reports the outputs from a meeting of over 50 hydrogeologists from water supply companies ("water companies" herein), regulators, consultancies and academia across England and Wales (UK) that was convened in July 2019 to consider current groundwater drought management, and to identify research needs. A brief overview of the hydrogeological and regulatory context in England is provided first, followed by a synthesis in four themes of the conclusions of the meeting and the challenges for researchers and practitioners.

\section{The hydrogeological and regulatory context}

Groundwater forms approximately $30 \%$ of water supplies in England (Ascott 2017). The most important aquifer in England is the Chalk, a dual porosity limestone aquifer with high vulnerability to droughts in comparison to other major aquifers with significant intergranular flow (Ascott et al. 
2019). Groundwater droughts occur episodically in England, with responses to historical droughts shaping current drought planning and management. In the context of the European Union Water Framework Directive, the 25-year Environment Plan (DEFRA 2018) sets out the policy framework in England for managing water resources and drought. Management of groundwater supplies in England are built on estimations of boreholes yields derived from pumping rate and water level data collected during droughts (Beeson 2000), in conjunction with abstraction licencing considering resource availability and environmental impacts (Environment Agency 2016). In the longer term, regulators have a vision in which water companies deliver long-term water supply resilience, cost efficiency and environmental stewardship (Ofwat 2019). In recognition of the need for drought research the Natural Environment Research Council (NERC), with other UK research councils, funded the UK Drought and Water Scarcity programme; the meeting reported here was part of that programme.

\section{Four key themes for management of groundwater supplies subject to drought}

\section{Joined-up definitions of drought}

Drought is a relative concept which results in many definitions (Van Loon 2015). Drought definitions and metrics depend on the type of drought (e.g. meteorological, streamflow, groundwater, water supply, agricultural, environmental), as well as hydrological and societal context. In countries with multiple water suppliers (e.g. the UK, USA, Germany, there can be regional differences in the definition of droughts over relatively small areas. In England, each water company sets their own "drought triggers" (typically groundwater levels in observation boreholes) to define drought status and when supply interventions such as temporary water use restrictions are imposed (Water UK 2016). With the agreement of customers and regulators, companies also define their own "levels of service" (planned frequency of such interventions) and drought resilience. This has resulted in differences across England, with the planned frequency of temporary water use restrictions ranging from 1 in 10 years to 1 in 100 years between neighbouring water companies (Water UK 2016). There may also be differences between perceptions of drought and scientific indicators of drought status, with the public more likely to identify a dry river (streamflow drought) than low groundwater levels (groundwater drought) during an extended period of dry weather (Salter and Singleton-White 2019).

These differences can make communications between stakeholders, including the public, challenging during drought events. This can be a particular problem where neighbouring water companies communicate different messages regarding drought status, even if this is for legitimate operational reasons (e.g. associated with different drought triggers and levels of service, as noted above). There is therefore a need for a more 'joined-up' and consistent approach in the use of drought definitions and how these are communicated to stakeholders, including the public. Public-facing frameworks which integrate different standardised drought metrics-e.g. Standardised Precipitation Index (McKee et al. 1993), Standardised Streamflow Index (Svensson et al. 2017) and the Standardised Groundwater level Index (Bloomfield and Marchant 2013) - with water supply indicators such as the Surface Water Supply Index (Doesken et al. 1991), and with measures of environmental drought stress (Slette et al. 2019), synthesized and presented in a nontechnical manner, could address this issue. There is precedent for this approach, for example the United States Drought Monitor (2020). Other countries where drought may affect groundwater could also benefit from such frameworks.

\section{Enhanced fundamental monitoring}

Well-maintained monitoring programmes and datasets are essential for planning and managing groundwater droughts. In England, groundwater level and pumping data from water supply boreholes are now routinely collected via telemetered transducers and flow meters. Whilst regulatory planning guidelines (DEFRA 2015) for water company actions during drought events stipulate requirements for monitoring of the surface environment (e.g. riverine ecological status), there are limited requirements for groundwater monitoring specifically. Consequently, telemetered groundwater levels from pumping boreholes may not necessarily be validated frequently using manual measurements, which is essential for accurate drought yield assessments. Water quality deterioration (e.g. increased turbidity, iron) can also cause reductions in boreholes yields during droughts (Beeson 2000); however, collection of these data is highly variable across both water companies in England and individual pumping boreholes. Telemetered groundwater levels from observation boreholes operated and maintained by the Environment Agency are also increasingly available for England (Shoothill 2019). A national drought surveillance network for monitoring the environmental impact of groundwater drought is in place (e.g. flows, levels and pollutant concentrations in streams and wetlands, and associated ecological impacts), as well as targeted case-by-case monitoring (Environment Agency 2017); however, there have been significant decreases over time in surface-water quality monitoring and freshwater invertebrate surveys in England (Environment Agency 2019a, b).

Enhanced collection of hydrogeological, hydrological and ecological data associated with groundwater droughts in England is essential if improved integrated models of groundwater in the water cycle are to be developed (see the following section). Future hydrogeological monitoring developments should evaluate existing monitoring networks, and aim to improve consistency in data collection across water supply 
sources and water companies. Improved validation and quality assurance/quality control of telemetered data through manual observations is required, during both dry and wet periods given the nonlinear and heterogeneous nature of groundwater systems. Enhanced monitoring could be achieved through regulatory interventions such as including stipulations on new pumping licences to require monitoring. Citizen science, fixed-point photography of streams and low-cost sensor technology also afford the possibility of extended monitoring of ecological impacts of drought. Enhanced monitoring is also important globally given the shift in water use from surface water to groundwater (Wada et al. 2012) and limited monitoring networks in developing countries.

\section{Improved integrated modelling of groundwater in the water cycle during droughts}

Water cycle models developed by practitioners in England are focussed in specific fields (e.g. groundwater, surface water, flooding, water resource systems and distribution networks) to address specific questions. Integration of models across fields has been limited in research and practice. Water resource system models (e.g. AQUATOR (Oxford Scientific Software 2008) and MISER (Ovarro 2020) used by water supply companies for operational and long-term water resources planning, generally have limited representation of groundwater processes. In contrast, distributed groundwater models (Shepley et al. 2012) are used by the environmental regulator for resource assessment and pumping licensing, but generally have not been coupled with resource system models. Only recently have coupled models of water quality, drought, climate change and water supply been developed for research purposes, and these represent groundwater simplistically (Mortazavi-Naeini et al. 2019).

Both water resource system and distributed groundwater models can be subject to long run times, which has limited the extent of uncertainty analysis that has been undertaken. Whilst models have used stochastically derived meteorological data (Harris et al. 2014) to explore resource availability under future droughts, limited work has explored the impact of groundwater model structure and parameter uncertainty, which may significantly affect yield estimates in the Chalk (Ascott et al. 2019). Integration of water quality has been limited in these models and there can be challenges in accessing models when these are based in proprietary software and contain commercially sensitive information. In England it has now been recognised that water resources planning at the water company level has resulted in a lack of integration of plans at the regional and national scale (Environment Agency 2020). There is now a desire to develop multi-sectoral, integrated approaches to water, wastewater and flood management planning at these scales (Environment Agency 2020). Such approaches can be supported by development of open source, integrated models of the full water cycle (resource and quality included) that integrate live data and can be run in real-time for operational decision support and forecasting, with evaluation of uncertainty included. This goal is ambitious and likely only realistic in the long term (>10 years), with efforts prioritised towards areas with greatest drought vulnerability. This can be facilitated through use of high-performance computing and centralised data stores, which have not yet been exploited in earnest in hydrogeological practice in England.

\section{Better information sharing}

Despite improvements in the open publication of data held by environmental regulators (Environment Agency 2019a, b), sharing of data and models used by practitioners for managing groundwater droughts has historically been limited. Previous research in England has suggested that limited availability and assessment of environmental data risks drought management planning being a "tick box" exercise (Cook 2017). To avoid this, transparency and sharing of models, tools and data used for groundwater drought monitoring, management and forecasting should be embedded in drought policy. This is not just between hydrogeologists (regulators, consultants, industry), but also between professionals in different fields (e.g. hydrogeologists and climate scientists) and between professionals and the public and other stakeholders. To this end, there is a requirement for services that provide both data (e.g. application programming interfaces) and, water supply security issues notwithstanding, public-facing outputs for nonspecialists. There also needs to be sharing of knowledge and experience in different approaches for drought management, so practitioners can be aware of existing practices and avoid repeating work. The recent development of a national water resources planning framework in England (Environment Agency 2020), collaborative groups of water companies for regional scale planning (e.g. Water Resources East 2019) and national stakeholder groups convened during periods of dry weather (Environment Agency 2017), give much potential to achieve this.

With groundwater droughts affecting water security globally, there is a need to improve drought management internationally. Sharing of knowledge between countries with different drought management approaches, as well as with cities that have recently experienced droughts - e.g. Cape Town, South Africa (Olivier and Xu 2019) —will support this and goals for global groundwater sustainability (Global Groundwater Statement 2019).

Acknowledgements We thank the participants of the AboutDrought workshop on "Groundwater Supply during Droughts" held on 1st July 2019 in Birmingham, UK. The views expressed in this paper are the authors' own, and not those of their respective organisations. The authors affiliated to BGS publish with permission of the Director, British Geological Survey (UK Research and Innovation).

Funding This research was funded by the BGS's Groundwater Science Directorate National Capability programme (UKRI); NERC's Drought 
and Water Scarcity Programme (NE/L010151/1, NE/L010178/1, NE/ L010070/1); and the NERC funded European Groundwater Drought Initiative (NE/R004994/1).

Open Access This article is licensed under a Creative Commons Attribution 4.0 International License, which permits use, sharing, adaptation, distribution and reproduction in any medium or format, as long as you give appropriate credit to the original author(s) and the source, provide a link to the Creative Commons licence, and indicate if changes were made. The images or other third party material in this article are included in the article's Creative Commons licence, unless indicated otherwise in a credit line to the material. If material is not included in the article's Creative Commons licence and your intended use is not permitted by statutory regulation or exceeds the permitted use, you will need to obtain permission directly from the copyright holder. To view a copy of this licence, visit http://creativecommons.org/licenses/by/4.0/.

\section{References}

Ascott MJ (2017) Groundwater resources in the UK. http://www.bgs.ac. uk/research/groundwater/waterResources/GroundwaterInUK/ home.html. Accessed 7 September 2020

Ascott MJ, Mansour M, Bloomfield JP, Upton KA (2019) Analysis of the impact of hydraulic properties and climate change on estimations of borehole yields. J Hydrol 577:123998. https://doi.org/10.1016/j. jhydrol.2019.123998

Beeson S (2000) The UKWIR methodology for the determination of outputs of groundwater sources: a review. Q J Eng Geol Hydrogeol 33:227-239. https://doi.org/10.1144/qjegh.33.3.227

Bloomfield JP, Marchant BP, McKenzie AA (2019) Changes in groundwater drought associated with anthropogenic warming. Hydrol Earth Syst Sci 23:1393-1408. https://doi.org/10.5194/hess-23-1393-2019

Cook C (2017) Drought planning in England: a primer. Environmental Change Institute, University of Oxford, Oxford, UK

DEFRA (2015) Drought plans: environmental assessment and monitoring. https://www.gov.uk/guidance/drought-plans-environmentalassessment-and-monitoring. Accessed 7 September 2020

DEFRA (2018) 25 year environment plan. https://assets.publishing. service.gov.uk/government/uploads/system/uploads/attachment data/file/693158/25-year-environment-plan.pdf. Accessed $\overline{7}$ September 2020

Doesken NJ, McKee TB, Kliest J (1991) Development of a surface water supply index for the western United States. Colorado Climate Center, Department of Atmospheric Science, Colorado State University, Fort Collins, CO. http://www.droughtmanagement. info/literature/CSU Development SWSI_Western United States 1991.pdf. Accessed 7 September 2020

Environment Agency (2016) Managing water abstraction. https://assets. publishing.service.gov.uk/government/uploads/system/uploads/ attachment_data/file/562749/LIT_4892.pdf. Accessed 7 September 2020

Environment Agency (2017) Drought response: our framework for England. https://assets.publishing.service.gov.uk/government/ uploads/system/uploads/attachment_data/file/625006/LIT_10104. pdf. Accessed 7 September 2020

Environment Agency (2019a) Freshwater and marine biological surveys for invertebrates England. https://data.gov.uk/dataset/ae610ec87635-4359-9662-c920046950f7/freshwater-and-marine-biologicalsurveys-for-invertebrates-england. Accessed 7 September 2020

Environment Agency (2019b) Water quality data archive. http:// environment.data.gov.uk/water-quality/view/download/new. Accessed 7 September 2020

Environment Agency (2020) Meeting our future water needs: a national framework for water resources. https://assets.publishing.service. gov.uk/government/uploads/system/uploads/attachment_data/file/ 872759/National Framework for water resources main report. pdf. Accessed 7 September $20 \overline{2} 0$

Global Groundwater Statement (2019) Global groundwater sustainability: a call to action https://www.groundwaterstatement.org/. Accessed 7 September 2020

Harris CNP, Quinn AD, Bridgeman J (2014) The use of probabilistic weather generator information for climate change adaptation in the UK water sector. Meteorol Appl 21:129-140. https://doi.org/10. 1002/met.1335

McKee TB, Doesken NJ, Kleist J (1993) The relationship of drought frequency and duration to time scales. Proceedings of the 8th Conference on Applied Climatology, American Meteorological Society, Boston, MA, pp 179-183

Mortazavi-Naeini M, Bussi G, Elliott JA, Hall JW, Whitehead PG (2019) Assessment of risks to public water supply from low flows and harmful water quality in a changing climate. Water Resour Res 55: 10386-10404. https://doi.org/10.1029/2018wr022865

Ofwat (2019) PR19 final determinations. https://www.ofwat.gov.uk/wpcontent/uploads/2019/12/UK-Government-priorities-and-our-2019price-review-final-determinations.pdf. Accessed 7 September 2020

Olivier DW, Xu Y (2019) Making effective use of groundwater to avoid another water supply crisis in Cape Town, South Africa. Hydrogeol J 27:823-826. https://doi.org/10.1007/s10040-018-1893-0

Ovarro (2020) MISER. https://ovarro.com/en/middle-east/solutions/ analytics/on-premise/miser/. Accessed 7 September 2020

Oxford Scientific Software (2008) Aquator: software for water resources modelling. http://www.oxscisoft.com/index.aspx. Accessed 7 September 2020

Salter M, Singleton-White S (2019) Chalk streams in crisis: a call for drought action now. https://www.theriverstrust.org/media/2019/06/ Chalk-streams-dossier June-2019 FINAL FINAL-1.pdf. Accessed 7 September 2020

Shepley MG, Whiteman MI, Hulme PJ, Grout MW (2012) Introduction: groundwater resources modelling: a case study from the UK. Geol Soc Lond Spec Publ 364:1-6. https://doi.org/10.1144/SP364.1

Shoothill (2019) GaugeMap. https://www.gaugemap.co.uk/. Accessed 7 September 2020

Slette IJ, Post AK, Awad M, Even T, Punzalan A, Williams S, Smith MD, Knapp AK (2019) How ecologists define drought, and why we should do better. Glob Chang Biol 25:3193-3200. https://doi.org/ 10.1111/gcb.14747

Smith M, Cross K, Paden M, Laban P (2016) Spring: managing groundwater sustainably. IUCN, Gland, Switzerland

Svensson C, Hannaford J, Prosdocimi I (2017) Statistical distributions for monthly aggregations of precipitation and streamflow in drought indicator applications. Water Resour Res 53:999-1018. https://doi. org/10.1002/2016wr019276

United States Drought Monitor (2020) United States Drought Monitor. https://droughtmonitor.unl.edu/. Accessed 7 September 2020

Van Loon AF (2015) Hydrological drought explained. WIREs Water 2: 359-392. https://doi.org/10.1002/wat2.1085

Wada Y, van Beek LPH, Sperna Weiland FC, Chao BF, Wu Y-H, Bierkens MFP (2012) Past and future contribution of global groundwater depletion to sea-level rise. Geophys Res Lett 39 doi:https:// doi.org/10.1029/2012GL051230

Water UK (2016) Water resources long-term planning framework. Water UK London

Water Resources East (2019) Water Resources East. https://wre.org.uk/ about-us/. Accessed 7 September 2020

Publisher's note Springer Nature remains neutral with regard to jurisdictional claims in published maps and institutional affiliations. 